\title{
THE IMPLEMENTATION OF REGIONAL POLICY IN SUPPORTING THE SUSTAINABLE REGIONAL FISHERY AFFAIRS OF EAST NUSA TENGGARA PROVINCE, INDONESIA
}

\author{
Pello J., Tinitadeus D.W. \\ University of Nusa Cendana, East Nusa Tenggara, Indonesia \\ *E-mail: jimmypello@yahoo.co.id
}

\begin{abstract}
This study aims to produce the ideas about "synchronizing the law of policy" of regional fisheries on an ongoing basis in order to achieve legal certainty from various policy instruments (beleid regels) which can be used as oppressive regulations. This supports the regional institutional policies, maritime agreement to protect and manage the business of capture fisheries, aquaculture, and regional conservation fisheries. This research is a normative legal research which shows an empirical legal aspect and was conducted in 10 regencies. Moreover, the fields of study include; (1) Regional Fisheries Policy; (2) Regional Fisheries Law; related to regional fisheries law and policy. The data were obtained through interviews and documentation. The information and data on legal materials were collected from each SKPD that becomes the research object. The results of the study point out that the Law and Policy of National Fisheries are not in line with the Law of the Regional government which also shows a constitutional conflict with Article 33 paragraph (3) of the 1945 Constitution. The Law and Policy of Regional Fisheries are still narrow and only focus on managing the capture fisheries but not on fishery cultivation.
\end{abstract}

\section{KEY WORDS}

Implementation, law, policy, regional, fisheries.

The policy and law in the field of fisheries is an instrument to protect the regional marine environment that can be used to protect the sustainability of marine and fisheries conservation. The law as a set of norms in its regulation is sometimes less accurate in placing the principle of sustainable fisheries so as to disrupt its legal concept related to the authority to manage capture fisheries, aquaculture, and conservation fisheries. This can be seen from the research of Pello (2012) that the regional policies in marine and fisheries management in East Flores region tend to threaten the preservation of regional fisheries. Pello J (2015) also found that there are central and regional institutions concerned with the management of Sawu marine waters conservation related to captured fisheries; whereas, other institutions require conservation fisheries and some even combine them. These conditions are influenced by various legal instruments that give authority to various national and regional institutions.

At the level of systematic legal regulation, the legal instruments for management policies and legal protection policies require an improvement in order to support a sustainable fisheries system. The inequality in the management of conservation fisheries is obvious if it is connected with capture fisheries and its problems. This happens because the policy and law have fewer roles or is not synchronous with the regulatory material causing a contradiction in the regulation between sub-systems and other sub-systems which have an impact in the implementation and enforcement of the law itself. Likewise, the contradiction in the regulation of legal concepts in legal norms between the elements in one sub-system will lead to the rigidity in the implementation of legal norms.

\section{LITERATURE REVIEW}

The Concept of Public Policy. Pressman and Widavsky (in Widodo, 2008: 17) defined public policy as a hypothesis that contains initial conditions and predictable consequences. Public policy must be distinguished from other forms of policy such as private policy. This is influenced by the involvement of non-government factors. 
Furthermore, Robert Eyestone (in Agustino, 2008: 6) believed that public policy is "the relationship between government units and their environment". Many people assume that the definition is still too broad to be understood because public policy can cover many things.

Thomas R Dye (in Rangkuti, 2005: 8), on the other hand, described public policy as "whatever government choose to do or not to do". This definition emphasizes that public policy is about the realization of "action" and is not a statement of the desire of the government or public officials alone. Besides that, the government's choice to not do something is also a public policy because it has the same influence (impact) with the government's choice to do something.

Based on the opinions of various experts above, it can be concluded that public policy is a series of actions taken (or not taken) by the government to solve the problems of the public or for the interest of the public. The policy to do something is usually contained in the provisions and/or legislation made by the government so that it has a binding and enforcing properties.

The Stages of Public Policy. The stages of public policy according to William Dunn (in Widodo 2008) are as follows; (1) Agenda preparation; (2) Policy formulation; (3) Policy adoption; (4) Policy implementation; and (5) Policy evaluation.

The Framework of Public Policy. Keban (2004: 31) said that the framework of public policy will be determined by several variables such as (1) the objectives to be achieved; (2) the kind of value preferences which need to be considered; (3) the resources that support the policies; (4) the ability of the actors involved in policy-making; (5) the environments that cover social, economic, political aspects, and so on; and (6) the strategies used to achieve the goals.

The Type of Public Policy. Many experts propose that this type of public policy is based on their respective perspectives. James Anderson (in Luan, 2007) distinguished public policy into four categories: (1) substantive policy versus procedural policy. The substantive policy is the policies that concern with what the government will do while the procedural policy is how the substantive policy be implemented. (2) Distributive policy versus regulatory policy versus redistributive policy. Distributive policy involves the distribution of services or benefits to the society or individuals. Regulatory policy is a policy in the form of restrictions or prohibitions on the behavior of individuals or community groups. Meanwhile, the redistributive policy is the policies that regulate wealth, income, and ownership or rights among various groups in society. (3) Maternal policy versus symbolic policy. The maternal policy is a policy that provides complete resource benefits to the target group while the symbolic policy is a policy that provides symbolic benefits to the target group. (4) Policies which are related to public goods and private goods. Public goods policy is a policy that regulates the delivery of goods or public services. On the other hand, private goods policy is a policy that regulates the supply of goods or services for the free market.

Sustainable Fisheries Management Policy. Sustainable fisheries management is a fisheries management policy which aims to protect fisheries resources in national and regional marine waters in particular. Sustainable fisheries related to the conservation concept of fish resources according to the Government Regulation number 60 of 2007 Article 4, includes (1) Ecosystems conservation; (2) Fish species conservation; and (3) Fish genetic conservation. In addition to that, ecosystem conservation is done through several activities such as (1) fish populations and habitat protection; (2) fish population and habitat rehabilitation; (3) research and development; (4) the utilization of fish resources and environmental services; (5) social economic development; (6) supervision and control; as well as (7) monitoring and evaluation. All these elements are very much needed data and information.

The concept of sustainable fisheries management policy is related to the concept of public policy which involves the "doing or not doing" from the government or other organizations. It is known that public policy is related to the initial conditions and consequences that can be predicted. Besides that, the policy-making is always based on the wishes of many people or organizations related to the efforts to achieve sustainable fisheries management.

The Establishment of Regional Law concerning the Cooperation in Fisheries. Indonesia is a state of law that divides its territory into provinces and regencies/cities. These regions 
consist of land and sea areas. In regard to the marine areas, Article 18 (4) of Law number 32 of 2004 stipulates that regions/cities have 4 nautical miles of sea territory. In the context of the authority to manage resources in the sea area, the regions are given the right to participate in carrying out the implementation, exploration, and exploitation of Marine Resources in its territory. The authority, in its application, is not accompanied by the regulations on procedures, mechanisms, and determination of the Regency/city sea area management limits. According to Nuswardani, the management of regional sea areas related to regional legal aspects needs to be linked to the perceptions of the Government, stakeholders, and the public about the determination of maritime boundaries and its management. The program of the District Government in the sea area and the formulation of Regional Regulations is the basis for the establishment of inter-regional cooperation bordering the sea area which acts as a solution to eliminate disputes over the management of marine areas.

Aquatic Conservation Policies and Strategies. According to Dahuri et al., the management of aquatic conservation areas is inseparable from the management of fish resources as a whole. The conservation of fish resources is an effort to protect and conserve fish resources to ensure the existence, availability, and sustainability of fish species for present and future generations. As aquatic, coastal, and small islands conservation efforts, the government has some policies which one of them is the establishment of national target delivered by President Susilo Bambang Yudhoyono in the Convention on Biological Diversity (CBD) Brazil, 2006. In there, the President proclaimed the program of 10 million hectares Marine Conservation Areas in 2010 and 20 million hectares in 2020. The President Declaration Regarding the Coral Triangle Initiative (CTI) at APEC Leaders Meeting in Sydney, 2007 was followed up by the Senior Official Meeting in 6 to 7 December 2007.

The national policy support in the development of aquatic conservation areas is created in a comprehensive and integrated manner which considers a decentralization in its implementation. Policies and regulations that govern the management of coastal areas are getting stronger with the promulgation of Law number 27 of 2007 concerning the Management of Coastal Areas and Small Islands. In regard to fish resources, this Law synergizes with various other Laws, including the Law number 5 of 1990 in concern with the conservation of biological resources and their ecosystems and the Law number 31 of 2004 in concern with fisheries. In connection with decentralization, the Law number 32 of 2004 concerning Regional government is the glue of the relationship between several Laws which are used as the content material in the preparation and implementation of regional policies.

\section{METHODS OF RESEARCH}

This research is a normative legal research which also shows an empirical legal aspect. The study was conducted in 10 regencies. Furthermore, the fields of the study include; (1) Regional Fisheries Policy; (2) Regional Fisheries Law; related to regional fisheries law and policy. The data collection techniques were carried out through interviews and documentation. The information and data on legal materials were collected from each SKPD that becomes the object of the research and were analyzed by using descriptive analysis method. The research took place in East Nusa Tenggara Province and Kota Kupang (Kupang City) because this research is related to regional laws and policies in the area of regional fisheries and marine management. In addition to that, the analysis of legal materials and regional policies is qualitative. The data analysis in this research is a descriptive data analysis.

\section{RESULTS AND DISCUSSION}

East Nusa Tenggara Regional Regulation number 3 of 2011 concerning the Control of Fisheries Business. The basic consideration for the formation of Regional Regulation number 3 of 2011 in concern with the Control of Fisheries Business emphasizes the utilization of fisheries resources that are fair for the welfare of local people as well as in the framework of preserving fisheries resources. From the aspects of regional law formation, the overall rules regarding the control of fisheries business include: (1) the granting of capture fisheries and 
conservation fisheries business licenses; (2) the empowerment of capture fisheries fleets; (3) the coordination of handling criminal acts in the field of fisheries; (4) the information systems and statistical data on fisheries; and (5) guidance and supervision.

Paying attention to the scope of legal material, it is shown that this regulation emphasizes the aspects of capture fisheries followed by aquaculture. The rules concerning capture fisheries include fishing licenses, boat facilities licenses, and fishing gear licenses that must be owned by large fishermen. In details, the legal provisions related to these aspects are as follows:

- Capture fisheries business licenses (Article 5, 7, 8, 9 (SIUP-T, SIPI, SIKPI - T), Permission Management Mechanism (Article 10, 11, 12,13, 14), the provisions on fisheries law related to the obligations are: obliged to implement the provisions of SIUP-T (Article 15, 16, and the validity period of Article 17, 18, 19);

- The cultivation fisheries business license (Article 6 (SIUP-B, SIKPI-B);

- The extension period of SIUP, SIPI, and SIKPI (Paragraph 4 Article 21-Article 26).

Referring to the 2 main things regulated in this regulation, it can be seen that the regional government of East Nusa Tenggara wants to control the capture fisheries activities related to the regulation of articles about fishing gear and its supporting facilities of $10 \mathrm{GT}$. In addition, it also regulates the authority of the provincial government to grant fishery licenses related to the use of fishery facilities from $30 \mathrm{GT}$ to $60 \mathrm{GT}$ (Article 62). Indirectly, this regional law also supports the regional government in an effort to increase the fleet of fishing boats and fishing gears. These conditions indirectly threaten the lives of fisheries and various conservation efforts.

Similar conditions also occur in the provision of aquaculture business. This is expected to bridge the disruption to the utilization of fisheries resources in the marine area yet the will of this legal provision emphasizes the cultivation aspect in terms of fisheries resources exploitation policies like seaweed while the cultivation of fast flowing fish species experiences a failure.

Broadly speaking, this regional regulation does not have a direct support to the aquatic conservation. This may arise if the provincial government correctly and firmly implements the provisions of fisheries business licenses and cultivation business licenses as well as those that are primarily concerned with the operation of capture fisheries and aquaculture. It is also expected to successfully reduce illegal fishing and conflicts between fishermen in East Nusa Tenggara.

East Nusa Tenggara Regional Regulation number 8 of 2009 concerning the Retribution of Fisheries Business Licenses. The validity of East Nusa Tenggara Regional Regulation number 8 of 2009 concerning the Retribution of Fisheries Business Licenses at the provincial level essentially regulates the object of levies related to the service of licensing levies in the field of fisheries and other related activities (SIUP, SIPI, SIKPI single operations, SIKPI fleet unit operations, and SIPR). All types of those levies are linked with the subject of fisheries business levies namely individuals and business entities that obtain such licensing services in the field of fisheries business. In other words, the two regional regulations above are interrelated legal provisions which regulate fisheries management with closed-access thinking. This strongly demonstrates fisheries exploitation for those who have business requirements in the field of fisheries. If all holders of the fisheries business licenses are legal, it is possible that this legal instrument indirectly hampers the purpose of marine conservation because the regulation does not prioritize the legal aspects of conservation fisheries.

Based on the results of interviews with port informants, the Development Planning Agency at Sub-National Level of East Nusa Tenggara found that there were still a number of regional regulations related to the management of marine conservation, such as:

- Regional regulation number 10 of 2007 concerning Retribution of Regional Resources Utilization;

- Regional regulation number 11 of 2007: The Retribution of Regional Production Sales

- Regional regulation number 12 of 2001: The Retribution of Port Service;

- Regional regulation number 13 of 2001: The Retribution of Fisheries Boats Testing.

The Regional Regulation number 11 of 2007 concerning the Retribution of Regional Production Sales stipulates that the price of fish seeds is set from IDR 150/head to IDR 
$30,000 /$ head. This regulation supports the aquaculture activities regarding the procurement of fish seeds in the context of aquatic conservation.

The Regional Regulation number 12 of 2001 concerning the Retribution of Port Service chapter VI article 8 paragraph (1) says that this regulation sets the levies which are classified according to the type of service provided, the size of the ship, and the period of usage while paragraph (2) serves that the rate is determined based on the prevailing market rates in East Nusa Tenggara and last but not least, paragraph (3) shows that the structure and size of the tariff is determined with some provisions such as mooring fees for $1 / 4$ eternal $x$ length of vessel $\times 375$ and cost of landing for $1 / 4$ eternal x GT x 150 as well as document service for ships to moor by IDR 35,000/ship.

In fact, this East Nusa Tenggara Regional Regulation does not directly support marine conservation because it emphasizes the aspects of East Nusa Tenggara government services rather than sustainable fisheries. This regulation indirectly supports capture fisheries business to increase fishermen's income but not closing down the possibility of threatening fisheries resources if the fishing equipment owned is not environmentally friendly such as the use of trawlers.

Besides being regulated in 2 separate regional regulations, the legal aspects of fisheries management are still related to other legal provisions that regulate certain parts of the coast which also confirm the aquatic conservation interests especially from the threat of marine pollution.

East Nusa Tenggara Governor Regulation number 38 of 2010 concerning the Management of Coral Reefs in East Nusa Tenggara Province. The philosophical foundation for the issuance of this regulation is the belief that coral reefs are important ecosystems that support water productivity including fisheries in the sea. However, in fact, the condition of those coral reefs is increasingly damaged due to some irresponsible activities. Therefore, the management of coral reefs in East Nusa Tenggara Province must be carried out by considering the balance between the utilization and preservation aspects in an integrated and synergistic manner in between East Nusa Tenggara Regional Government and related stakeholders.

In Article 7, it is explained that:

- The utilization of coral reef ecosystems is limited to the interests of conservation, sustainable fisheries, research and development, education and training, and environmentally friendly marine tourism.

- The utilization of coral reef ecosystems for trading can only be carried out through coral cultivation/transplant activities that receive Governor's Approval.

- The natural utilization of coral reefs is not permitted in an aquatic conservation area.

Although the efforts of coral reef management are detail enough, the status of this regulation as a Governor Regulation has a consequence that there is no regulation regarding sanctions for violations. The socialization and enforcement of this regulation have not been carried out well especially at the Regency/city level.

Legal Aspects at the Regency Level: Kupang City Regional Regulation. Kupang City Regional Regulation number 21 of 2007 in concern with the Management of Coastal Areas is formed due to several considerations such as that the coastal area of Kupang City has a diverse biological and non-biological natural resources as well as potentially economic environmental services which can be used to improve the welfare of the people especially coastal communities; coastal areas need to be managed in an integrated manner so as to create a balance in supporting the sustainable development with the efforts to utilize, develop, protect, and preserve coastal resources that are environmentally-friendly and responsible through community empowerment.

According to this regulation, the provisions related to fisheries management that is presented in Paragraph 3 in concern with Coastal Zoning Plans particularly in Article 13, confirms that:

- The preparation and determination of RZ are guided by the RS;

- $R Z$ indicates that the allocation of coastal resources utilization is based on its carrying capacity; 
- $\mathrm{RZ}$ is used to guide the utilization and prevent the conflicts of coastal resources utilization.

In the regional management stipulated in article 13, business actors must have a license with various requirements including activities that may not be carried out including the regional government as confirmed in the provisions of Article 14 as follows: Zoning Plans consist of; (1) a. Allowable activities; (2) b. Prohibited activities; and (3) c. Activities that require permission.

Likewise, the provisions related to fisheries business are also regulated in Article 15:

(1) RZ, as referred to in Article 13 paragraph (1), consists of: Conservation zone; General utilization zone; Certain zone; and Path.

(2) The zones as referred to in paragraph (1) are further elaborated in the Detailed Zone Plan.

By looking at the provisions of this regional regulation, it is still necessary to have a regional legal provision that is related to Kupang City Strategic Plan and also the Mayor's Regulation on the physical buildings program on the coast. However, these provisions have not been established yet so that the legal provisions on the coastal area still considered incomplete and threaten Sawu marine waters conservation. This is important because the coastal law and the development of Kupang City and some of the areas that surround Sawu Sea are very dynamic.

Kupang City does not have a legal provision in regards to fisheries. However, the fisheries conservation is specifically regulated in the coastal regional regulation especially in Part 3 (Conservation) of Paragraph 1 (General) in the provisions of Article 25:

(1) The conservation is carried out with the aim to:

a. keep the sustainability of coastal ecosystems;

b. protect the migration path of fish, marine biota, and its habitat; and

c. protect traditional culture sites.

(2) The conservation areas characterized as a single ecosystem are aimed to protect:

a. fish resources;

b. migration path of whales and endangered species;

c. the place for fish spawning;

d. certain areas regulated by traditions/customs; and

e. coastal ecosystems that are unique/vulnerable to change.

(3) Proposing the status of the conservation area as referred to in paragraph

(2) It can be carried out by individuals, community groups, and/or by the Regional Government based on the characteristics of the region supported by scientific data and information.

The regional regulation also regulates the zoning in the sea as shown in the formulation of the provisions of Article 26 of Conservation Area as referred to in Article 25 paragraph (2) that is divided into 3 zones, namely: a. Core zone; b. Buffer zone; and c. Limited use zone. Likewise, the regional conservation areas are regulated in Paragraph 2 concerning Marine Conservation Areas in Article 27. It is said that the Mayors must determine the coastal conservation areas, fisheries asylum, regional marine conservation areas for coral reefs, seagrass beds, beaches, estuaries, and/or mangrove forests.

Based on the explanation above, it is clear that the legal aspects produced by the Regional Government both in provincial and regency/city level do not thoroughly regulate the marine conservation but only capture fisheries. This can occur because the focus of the regional government is on the efforts to increase the revenues from regional fisheries to support regional development especially in physical and infrastructure construction within the regional fisheries business. The law and regulation of regional fisheries itself have not been regulated separately because regional politicians and local governments do not consider this matter to be very important due to the limited understanding of prioritizing regional fisheries regulation. In line with the changes in legal politics in the field of the central government to today's regional life, the aspect of fisheries is one of the parts that the authority of its legal arrangements is partially withdrawn to be regulated at the provincial level. The legal consequence is that the regency/city regional government is no longer compiling the regional legal instruments but is left to the provincial government and legislature. The thing that 
concerns the researchers is that the management and regulation of law cannot support each. As an example, the fisheries production management and marketing is maximized because the interests of the regencies and provinces are not synchronized so that it will create a conflict of interest which ignores the regional fisheries conservation but then highlights the regional capture fisheries.

In connection with the regulation of fishing license (surat izin penangkapan ikan or SIPI) and fisheries business license (surat izin usaha perikanan or SIUP), the Governor of East Nusa Tenggara Province has arranged East Nusa Tenggara Governor Regulation number 51 of 2009 concerning the delegation of authority from the governor to the Head of KPPTSP to sign certain licenses within East Nusa Tenggara provincial government on November 23, 2009.

\section{CONCLUSION}

The national fisheries law and policy arrangements are not in line with the regional law which also shows a constitutional conflict with Article 33 paragraph (3) of the 1945 Constitution. The regional fisheries law arrangements are still limited and only regulate capture fisheries management. This is also known to have a little concern on aquaculture. In East Nusa Tenggara, all regions do not have a fishery law instruments in specific considering that the regulating authority has been drawn to the province. The implementation of the new Regional Government Law number 19 of 2015 in replace to the Law number 23 of 2014 does not change the legal provisions concerning the limitation of legal regulation in the municipal area in regards to the authority to supervise the regional fisheries management so that it is likely to threaten the regional conservation fisheries.

\section{SUGGESTIONS}

The renewal of regional fisheries regulation requires changes starting from the fisheries law and adjusted to the will of Article 33 paragraph (3) and Article 18 paragraph (5) of the 1945 Constitution and other related legal instruments.

The region also needs to be granted an authority to manage and supervise the regional fisheries in an autonomous manner and manifested through regional fisheries law and regulation based on the authority delegation.

The party from the municipal also needs an authority to supervise the regional fisheries management in an effort to support the implementation of fisheries conservation law in the region and the city.

\section{REFERENCES}

1. Pello, J. (2012). Implemetasi Pilihan Kebijakan Hukum Kelautan dan Perikanan, Dalam Menunjang Pengelolaan Perikanan Daerah Secara Berkelanjutan Oleh Dinas Kelautan dan Perikanan Kabupaten Flores Timur. Research Report. In cooperation with WWF SolorAlor Project, Kupang.

2. Pello, J \& D.W. Tinitadeus. (2015). Imlementasi Hukum Kebijakan Perikanan Dalam Menunjang Sistem Perikanan Laut Daerah Secara Berkelanjutan. Research Report. Grant of Pascasarjana, Universitas Nusa Cendana.

3. Latif, A. (2010). ukum dan Kebijakan (Beleidregel) pada Pemerintahan Daerah. Yogyakarta: UII Press.

4. Agustino, L. (2008). Dasar-Dasar Kebijakan Publik. Bandung: Alfabeta.

5. Widodo, J. (2008). Analisis Kebijakan Publik. Malang: Bayu Media.

6. Rangkuti, S.S. (2005). Hukum Lingkungan Dan Kebijaksanan Lingkungan Nasional, Surabaya: Airlangga University Press.

7. Keban, J. (2004). Enam Dimensi Strategis Administrasi Publik, Konsep, Teori dan Isu. Yogyakarta: Grava Media.

8. Luan, K.B. (2007). Analisis Kebijakan Publik Dalam Proses Pengambilan Keputusan.

9. Dahuri, A., Rais, J., Ginting, S.P., Sutepu, M.J. (1996). Pengelolaan Sumberdaya Pesisir dan Lautan Secara Terpadu. Jakarta: Pradnya Pratama. 